UDC 624.073:539.3+624.075

R.M. Tatsiy ${ }^{1}$, DSc, Prof.,

T.I. Ushak ${ }^{2}, \mathrm{PhD}$

${ }^{1}$ Lviv State University of Life Safety, 35 Kleparivska Str., 79000 Lviv, Ukraine; e-mail: 1dubzh.lviv@mns.gov.ua

2 "Levadiia Proekt", 8 Staryy Rynok Square, 79000 Lviv, Ukraine

\title{
DISCRETIZATION METHOD USED TO RESOLVE THE RECTANGULAR PLATES' STABILITY PROBLEM, CASE OF SINGULAR ELASTIC FOUNDATION
}

\begin{abstract}
P.M. Тацій, T.I. Ушак. Метод дискретизації в задачі про стійкість прямокутних плит на сингулярній пружній основі. В даній статті запропонований новий наближений метод розв'язання задач про стійкість прямокутних плит на сингулярній пружній основі. Задача знаходження критичних сил зводиться до розв'язання диференціальних рівнянь 3 сингулярними коефіцієнтами у формі дельта-функцій. В основу методу покладено апроксимацію коефіцієнтів відповідних диференціальних рівнянь узагальненими функціями. Стаття містить порівняльні результати $\mathrm{i}$ демонструє ефективність методу при розв'язуванні задач про стійкість. Отримані нові результати, невідомі в спеціалізованій літературі.

Ключові слова: метод дискретизації, узагальнене квазідиференціальне рівняння 4-го порядку, сингулярна пружна основа, задача про стійкість.
\end{abstract}

R.M. Tatsiy, T.I. Ushak. Discretization method used to resolve the rectangular plates' stability problem, case of singular elastic foundation. The authors propose a new approximate method for solving the rectangular plates' stability with a singular elastic base problem. The problem of critical forces' determination is reduced to solving a set of differential equations with singular coefficients in the form of delta functions. Proposed methods is based on these differential equations ${ }^{*}$ coefficients approximation with generalized functions. Authors present a comparative study which demonstrates the elaborated method efficiency when applied to stability problems. Principally new results not considered earlier with the special sources are obtained.

Keywords: discretization, generalized $4^{\text {th }}$ order quasi-differential equations, singular elastic base, stability problems.

Introduction. To investigate under load the stability of plates having an elastic foundation, as a rule, used are the approximate methods $[1,2]$. But the accurate solutions are obtained only, few exceptions made, for differential equations with constant coefficients. An effective way to study the separate plates' and plated systems' dynamics and stability is embodied with a method these recent years proposed by [3] authors and known as the boundary elements method (BEM). However, when model parameters' discrete-continuous distribution takes place, the differential equations' integration using standard techniques is associated with considerable difficulties or the complex basic functions' emergence. Considered is the elastic foundation singular model, when stiffness coefficients $k_{i}(x)$ contain features of $\delta$-function's and its derivatives' type. The article considers a proposed solution to the problem of elastic foundation-based plates' stability loss on using quasi-differential equation (QDE) with generalized coefficients. It uses a discretization sampling method $[4,5]$, based on the concept of quasi-derivatives' for QDE with generalized coefficients and the corresponding linear differential equations' systems solutions approximation with measures [6].

Statement of the stability problem for rectangular plates based on elastic foundation and elastic supports. We shall consider a rectangular plate of constant thickness, which is located on a single-layer elastic foundation loaded with longitudinal compressive forces $N_{x}=N$ (Fig. 1).

These plates' stability equation will get the formulation [1]:

DOI 10.15276/opu.2.46.2015.08

(C) 2015 The Authors. This is an open access article under the CC BY license (http://creativecommons.org/licenses/by/4.0/). 


$$
D \nabla^{2} \nabla^{2} y-k_{2} \nabla^{2} y+k_{1} y+N \frac{\partial^{2} y}{\partial x^{2}}=0
$$

where $D=\frac{E H^{3}}{12\left(1-\mu^{2}\right)}-$ plate's cylindrical stiffness;

$E$ - plate material elasticity modulus;

$G=\frac{E}{2(1+\mu)}-$ concrete shift modulus;

$\mu$ - Poisson's coefficient,

$H$ - plate thickness;

$$
\begin{aligned}
& k_{1}(x, z)=k_{10}(x, z)+\sum_{i} k_{1 i}(z) \delta\left(x-x_{i}\right) ; \\
& k_{2}(x, z)=k_{20}(x, z)+\sum_{i} k_{2 i}(z) \delta\left(x-x_{i}\right)-
\end{aligned}
$$

elastic foundation stiffness coefficients [7].

Function $\delta\left(x-x_{i}\right)$ at formula (2) represents the Dirac $\delta$ - function with carrier at the point $x=x_{i}$.

The $k_{1}$ coefficient determines the elastic foundation's compressive work and the $k_{2}$ coefficient determines the foundation's shifting (shearing) work. Determining coefficients as by (2) allows taking into account the continuously distributed reaction forces influencing the plate work as well as the discrete parameters (elastic supports and reaction torque in line with the coordinate $x=x_{i}$ ).

From the elastic supports' side the rod is prone to concentrated reactions $k_{1 i} y$-proportional to corresponding supports' linear displacements as well as to reaction torques $k_{2 i} y^{\prime}$-proportional to the supports' section angle of rotation

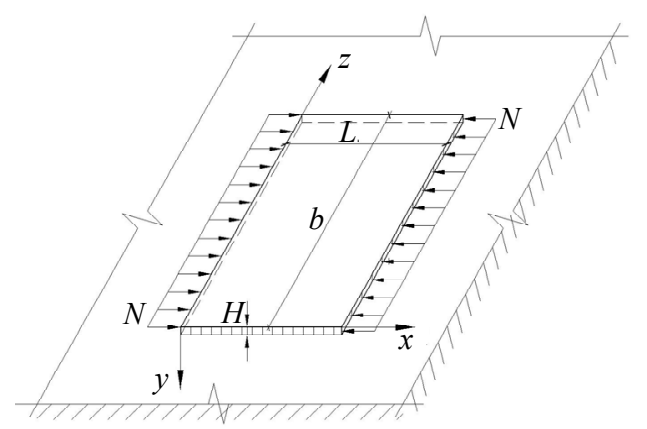

Fig. 1. Rectangular plate respectively to the axe $y$. The supports' flexibility at linear movement is characterized by the stiffness compression coefficient $k_{1 i}$, and their rotational suppleness is characterized by stiffness ratcheting coefficient $k_{2 i}$. Concentrated moments and elastic supports' reactions are directed oppositely to the supports' rotational and linear movement. Let we assume for simplicity that the elastic foundation stiffness coefficients are stable by the coordinate $z$.

The edges of the plate $z=0$ and $z=b$ are assumed to be freely supported:

$$
y_{z=0}=\left.\frac{\partial^{2} y}{\partial z^{2}}\right|_{z=0}=y_{y=b}=\left.\frac{\partial^{2} y}{\partial y^{2}}\right|_{z=b}=0 .
$$

The equation (1) solution shall be found using a single trigonometric series [7]

$$
y(x, z)=\sum_{k=1}^{\infty} Y_{k}(x) \sin \frac{k \pi z}{b} .
$$

Introducing (3) into (1) we get the equation

$$
Y_{k}^{I V}+\left[\frac{N-k_{2}(x)}{D}-2\left(\frac{k \pi}{b}\right)^{2}\right] Y_{k}^{\prime \prime}+\left[\left(\frac{k \pi}{b}\right)^{4}+\frac{k_{2}(x)}{D}\left(\frac{k \pi}{b}\right)^{2}+\frac{k_{1}(x)}{D}\right] Y_{k}=0 .
$$

Generalized $4^{\text {th }}$ order quasi-differential equation. We consider within the actual axe's open interval $E$ the equation:

$$
\left(a_{0}(x) y^{\prime \prime}\right)^{\prime \prime}+a_{2}(x) y+\left(a_{1}(x) y^{\prime}\right)^{\prime}=0,
$$

where $a_{0}^{-1}(x)$ - a function, locally limited and measured at $I$; 
$I$ - open interval of real axis;

$a_{1}(x)=b_{1}^{\prime}(x) ; a_{2}(x)=b_{2}^{\prime}(x) ; b_{0}(x) ; b_{1}(x) ; b_{2}(x)$ - functions of a variation locally limited at $I$ (class $\left.B V_{l o c}^{+}(I)[8]\right)$;

$b_{1}^{\prime}(x), b_{2}^{\prime}(x)$ - generalized derivatives (measured at $I$ ) [8].

To resolve the equation (5) we introduce the quasi-derivatives in such a manner:

$$
\begin{gathered}
y^{[0]}(x) \stackrel{\text { def }}{\equiv} y(x) ; y^{[1]}=y^{\prime}(x) ; y^{[2]}=a_{0} y^{\prime \prime}(x) ; \\
y^{[3]}(x)=a_{1} y^{\prime}(x)+\left(a_{0} y^{\prime \prime}(x)\right)^{\prime} .
\end{gathered}
$$

The initial QDE (5) is reduced into a system of $1^{\text {st }}$ order equations

$$
\mathbf{Y}^{\prime}(x)=C^{\prime}(x) \mathbf{Y}(x)
$$

where

$$
\mathbf{Y}(x)=\left(\begin{array}{c}
y \\
y^{[1]} \\
y^{[2]} \\
y^{[3]}
\end{array}\right) ; C^{\prime}(x)=\left(\begin{array}{cccc}
0 & 1 & 0 & 0 \\
0 & 0 & a_{0}^{-1}(x) & 0 \\
0 & -a_{1}(x) & 0 & 1 \\
-a_{2}(x) & 0 & 0 & 0
\end{array}\right) .
$$

The system (7) is correct [8], as the necessary and sufficient accuracy condition is satisfied:

where $\Delta C(x)=C(x)-C(x-0)=\left(\begin{array}{cccc}0 & 0 & 0 & 0 \\ 0 & 0 & 0 & 0 \\ 0 & -\Delta b_{1}(x) & 0 & 0 \\ -\Delta b_{2}(x) & 0 & 0 & 0\end{array}\right)-$

matrix of this system displacements;

Let $B(x, s)$ - is the fundamental matrix of system (7), which structure is well studied at works $[8,9]$, characterized with such features:

1. $B(s, s)=E$, where $E$ - unity matrix;

2. $B(x, s)=(E+\Delta \mathbf{C}(x)) \cdot B(x-0, s)$;

3. $\forall x_{1}, x_{2}, x_{3} \in I B\left(x_{3}, x_{2}\right) \cdot B\left(x_{2}, x_{1}\right)=B\left(x_{3}, x_{1}\right)$.

Using this matrix for an arbitrary initial vector $\mathbf{Y}_{0}=\mathbf{Y}\left(x_{0}\right), x_{0} \in I$, we can write down the solution get for the system (3) as

$$
\mathbf{Y}(x)=B\left(x, x_{0}\right) \mathbf{Y}_{0} .
$$

Proceeding to the equation's (5) variable coefficients approximation, we divide the rod having a length $l$ into $n$ equal parts. Let the initial point is $x_{0}=0$, the ending one $x_{n}=l$, and the dividing step $h=x_{k+1}-x_{k}$, at $k=0, \ldots, n$.

The approximation of $a_{0}(x)$ coefficient is following ( $l$-approximation [6]). At every interval $\left[x_{k} ; x_{k+1}\right)$ the $a_{0}(x)$ value is stable:

$$
a_{0}(x) \approx \frac{b_{0}\left(x_{k+1}\right)-b_{0}\left(x_{k}\right)}{h}=a_{k}, x \in\left[x_{k}, x_{k+1}\right),
$$

where $b_{0}(x)=\int_{0}^{x} a_{0}(t) d t$.

We proceed to respective [10] approximation of coefficients $a_{2}(x)=b_{2}^{\prime}(x)$ and $a_{1}(x)=b_{1}^{\prime}(x)$ ( $d$ - approximation) within the interval $\left[x_{k} ; x_{k+1}\right)$ : 


$$
\begin{aligned}
& a_{1}(x) \approx b_{1}\left(x_{k}\right) \delta\left(x-x_{k}\right) \stackrel{\text { def }}{=} c_{k} \delta\left(x-x_{k}\right), \\
& a_{2}(x) \approx b_{2}\left(x_{k}\right) \delta\left(x-x_{k}\right) \stackrel{\text { def }}{=} d_{k} \delta\left(x-x_{k}\right),
\end{aligned}
$$

where $\delta\left(x-x_{k}\right)$ - the Dirac $\delta$-function containing carrier at the point $x=x_{k}$.

Approximation performed the QDE (5) will appear as:

$$
\left(\sum_{k=0}^{n-1} a_{k} \theta_{k} y_{n}^{\prime \prime}\right)^{\prime \prime}+\left\{\sum_{k=0}^{n-1} d_{k} \delta\left(x-x_{k}\right)\right\} y_{n}+\left[\left\{\sum_{k=0}^{n-1} c_{k} \delta\left(x-x_{k}\right)\right\} y_{n}^{\prime}\right]^{\prime}=0
$$

representing a particular (actualized) case of QDE (1),

where $\theta_{k}$ - characteristic function of the interval $\left[x_{k} ; x_{k+1}\right): \theta_{k}=\left\{\begin{array}{l}1, x \in\left[x_{k}, x_{k+1}\right], \\ 0, x \notin\left[x_{k}, x_{k+1}\right] .\end{array}\right.$

Known is [6] that at $n \rightarrow \infty$ all solutions of the equation (15) together with their quasiderivatives $y^{[1]}, y^{[2]}$ and $y^{[3]}$ are equally directed to the corresponding solutions and quasi-derivatives of the equation (5):

$$
\lim _{n \rightarrow \infty}\left|y_{n}^{[i]}(x)-y(x)^{[i]}\right|=0, \quad i=\overline{0,3} .
$$

In this case the displacements matrix (10) will be

$$
\Delta C\left(x_{k}\right)=\left(\begin{array}{cccc}
0 & 0 & 0 & 0 \\
0 & 0 & 0 & 0 \\
0 & -c_{k} & 0 & 0 \\
-d_{k} & 0 & 0 & 0
\end{array}\right)
$$

Coefficients $a_{0}, a_{1}, a_{2}$, determined in such a way, the fundamental matrix $B\left(x_{k+1}, x_{k}\right)$ of quasidifferential equation $\left(a_{0} y^{\prime \prime}\right)^{\prime \prime}=0$ will take the shape [9]:

$$
B\left(x_{k+1}, x_{k}\right)=\left(\begin{array}{cccc}
1 & h & \frac{h^{2}}{2 ! a_{k}} & \frac{h^{3}}{3 ! a_{k}} \\
0 & 1 & \frac{h}{a_{k}} & \frac{h^{2}}{2 ! a_{k}} \\
0 & 0 & 1 & h \\
0 & 0 & 0 & 1
\end{array}\right) .
$$

The differential system (7) fundamental matrix, considering properties (11) can be found, using the formula [9]:

$$
B\left(x_{n}, x_{0}\right)=B(l, 0)=\prod_{k=0}^{n-1}\left(E+\Delta C\left(x_{k}\right)\right) B\left(x_{k+1}, x_{k}\right) .
$$

The matrix $B(l, 0)$ can also be built in other way [11].

Implementation of discretization method at rectangular plate stability problem when elastic foundation combined to elastic supports. Let us consider the stability problem for reinforced concrete rectangular plate with elastic foundation and elastic supports (Fig. 1), the length at $z$ axis being $30 \mathrm{~m}$, and length at $x$ axis making $20 \mathrm{~m}$. The plate edges $z=0$ and $z=b=30 \mathrm{~m}$, as well as $x=0$ and $x=L=20 \mathrm{~m}$ are supported with articulated linkage. The free edge $x=20 \mathrm{~m}$ is proportionally compressed with $N_{x}=N$ force. The plate thickness is $H=0,1 \mathrm{~m}$. The plate material characteristics $E=2,7 \cdot 10^{7} \mathrm{kPa}$, $\mu=0,167$ - respectively the elasticity modulus and the plate material's Poissonian coefficient. The elastic supports are positioned along $z$ axis, at the points $x_{i}=2 ; 4 ; 6 ; 8 ; 10 ; 12 ; 14 ; 16 ; 18 \mathrm{~m}$. The elastic singular foundation stiffness is determined with stiffness coefficients $k_{1} ; k_{2}(2)$. 
According to [1]

$$
k_{10}=\frac{E_{0} s_{11}}{\left(1-\mu_{0}^{2}\right)} ; k_{20}=\frac{E_{0} r_{11}}{2\left(1+\mu_{0}\right)} .
$$

Constant values at the expressions (20) are defined with such formulae:

$$
\begin{gathered}
E_{0}=\frac{E}{1-\mu^{2}} ; \mu_{0}=\frac{\mu}{1-\mu} ; r_{11}=\int_{0}^{H_{1}} \psi^{2}(y) d y ; \\
s_{11}=\int_{0}^{H_{1}}\left[\psi^{\prime}(y)\right]^{2} d y ; .
\end{gathered}
$$

where $E=3,2 \cdot 10^{4} \mathrm{kPa}$ - elasticity modulus;

$\mu=0,3$ - Poisson's ratio of foundation;

$\psi(y)$ - foundation settling transversal distribution non-dimensional function.

Case of a thin enough layer (thickness of $H_{1}=2 \mathrm{~m}$ ) characterized with normal tension stability, we can assume [1]:

$$
\psi(y)=\frac{H_{1}-y}{H_{1}} .
$$

At that the coefficients (21) are found according to [1]:

$$
\begin{gathered}
r_{11}=\int_{0}^{H_{1}} \psi^{2}(y) d y=\frac{H_{1}}{3} ; \\
S_{11}=\int_{0}^{H_{1}}\left[\psi^{\prime}(y)\right]^{2} d y=\frac{1}{3} .
\end{gathered}
$$

The coefficient of support compression stiffness $k_{11}$ and the support ratcheting stiffness coefficient $k_{21}$ would be found [1] using formula (20), where the coefficients $r_{11}, s_{11}$ are:

$$
\begin{aligned}
& s_{11}=10 H \int_{0}^{H_{1}}\left[\psi^{\prime}(y)\right]^{2} d y=\frac{10 H}{3} ; \\
& r_{11}=10 H \int_{0}^{H_{1}} \psi^{2}(y) d y=\frac{10 H_{1} H}{3} .
\end{aligned}
$$

Let we introduce into equation (4) the $\alpha=0 ; 1$, and $\beta=0 ; 1$. parameters. Then the stability problem for a rectangular plate supported with elastic foundation and elastic supports will be reduced to solving a generalized $4^{\text {th }}$ order QDE (GQDE)

$$
\begin{gathered}
Y_{k}^{I V}+\left[\frac{N-\beta k_{20}(x)}{D}-\frac{1}{D} \sum_{i} \alpha k_{21} \delta\left(x-x_{i}\right)-2\left(\frac{k \pi}{b}\right)^{2}\right] Y_{k}^{\prime \prime}+ \\
+\left[\left(\frac{k \pi}{b}\right)^{4}+\frac{\beta k_{20}(x)+\sum_{i} \alpha k_{21} \delta\left(x-x_{i}\right)}{D}\left(\frac{k \pi}{b}\right)^{2}+\right. \\
\left.+\frac{\beta k_{10}(x)+\sum_{i} \alpha k_{11} \delta\left(x-x_{i}\right)}{D}\right] Y_{k}=0
\end{gathered}
$$

with next boundary conditions

$$
\begin{gathered}
y(0)=y^{\prime \prime}(0)=y^{\prime \prime}(1)=0 ; \\
y^{\prime \prime \prime}(1)+\left[\frac{N-\beta k_{20}(x)}{D}-\frac{1}{D} \sum_{i} \alpha k_{21} \delta\left(x-x_{i}\right)-2\left(\frac{k \pi}{b}\right)^{2}\right] y^{\prime}=0 .
\end{gathered}
$$


To resolve the (25) equation, we designate the quasi-derivatives in such a manner:

$$
\begin{gathered}
y^{[0]}(x) \stackrel{\text { def }}{\equiv} y(x) ; y^{[1]}(x)=y^{\prime}(x) ; y^{[2]}(x)=y^{\prime \prime}(x) \\
y^{[3]}(x)=y^{\prime \prime \prime}(x)+\left[\frac{N-\beta k_{20}(x)}{D}-\frac{1}{D} \sum_{i} \alpha k_{21} \delta\left(x-x_{i}\right)-2\left(\frac{k \pi}{b}\right)^{2}\right] y^{\prime} .
\end{gathered}
$$

The initial QDE (25) shall be reduced to the $1^{\text {st }}$ order equations system

$$
\mathbf{Y}^{\prime}(x)=C^{\prime}(x) \mathbf{Y}(x) \text {, }
$$

$$
\begin{gathered}
\text { where } \mathbf{Y}(x)=\left(\begin{array}{c}
y \\
y^{[1]} \\
y^{[2]} \\
y^{[3]}
\end{array}\right) ; C^{\prime}(x)=\left(\begin{array}{cccc}
0 & 1 & 0 & 0 \\
0 & 0 & 1 & 0 \\
0 & -f_{1} & 0 & 1 \\
-f_{2} & 0 & 0 & 0
\end{array}\right) ; \\
f_{1}=\frac{N-\beta k_{20}(x)}{D}-\frac{1}{D} \sum_{i} \alpha k_{21} \delta\left(x-x_{i}\right)-2\left(\frac{k \pi}{b}\right)^{2} ; \\
f_{2}=\left(\frac{k \pi}{b}\right)^{4}+\frac{\beta k_{20}(x)+\sum_{i} \alpha k_{21} \delta\left(x-x_{i}\right)}{D}\left(\frac{k \pi}{b}\right)^{2}+\frac{\beta k_{10}(x)+\sum_{i} \alpha k_{11} \delta\left(x-x_{i}\right)}{D} .
\end{gathered}
$$

Using the fundamental matrix $B\left(x, x_{0}\right)$ for an arbitrary initial vector $\mathbf{Y}_{0}=\mathbf{Y}\left(x_{0}\right), x_{0} \in I$, we write down the system (28) solution as (12).

We proceed to discretization according to following scheme. We divide the interval $[0, L]$ with $x_{0}=0, x_{1}, x_{2}, \ldots, x_{n}=L$ points into $n$ equal parts, the by-unit length of every part (dividing step) is equal to $\frac{L}{n}=h$. Instead of the equation (25) we consider the $n$-th approximation QDE (discretization method)

$$
\begin{gathered}
y_{n}{ }^{I}+\left\{\left(\frac{N-\beta k_{20}(x)}{D}-2\left(\frac{k \pi}{b}\right)^{2}\right) h \sum_{k=0}^{n-1} \delta\left(x-x_{k}\right)-\frac{1}{D} \sum_{i=0}^{9} \alpha k_{21} \delta\left(x-x_{i}\right)\right\} y_{n}{ }^{\prime \prime}+ \\
+\left[\left\{\left(\frac{k \pi}{b}\right)^{4}+\frac{\beta k_{20}(x)}{D}\left(\frac{k \pi}{b}\right)^{2}+\frac{\beta k_{10}(x)}{D}\right\} h \sum_{k=0}^{n-1} \delta\left(x-x_{k}\right)+\frac{1}{D} \sum_{i=0}^{9}\left(\alpha k_{11}+\alpha k_{21}\left(\frac{k \pi}{b}\right)^{2}\right) \delta\left(x-x_{i}\right)\right] y_{n}=0 .
\end{gathered}
$$

At such case the displacements' matrix (10) is

$$
\Delta C\left(x_{k}\right)=\left(\begin{array}{cccc}
0 & 0 & 0 & 0 \\
0 & 0 & 0 & 0 \\
0 & -\left(\frac{N-k_{20}(x)}{D}-2\left(\frac{k \pi}{b}\right)^{2}\right) h & 0 & 0 \\
-\left(\left(\frac{k \pi}{b}\right)^{4}+\frac{k_{20}(x)}{D}\left(\frac{k \pi}{b}\right)^{2}+\frac{k_{10}(x)}{D}\right) h & 0 & 0 & 0
\end{array}\right) .
$$

Exemption made for $x_{i}$ points at which the displacement matrix appears as

$$
\Delta C\left(x_{i}\right)=\left(\begin{array}{cccc}
0 & 0 & 0 & 0 \\
0 & 0 & 0 & 0 \\
0 & -f_{1 i} & 0 & 0 \\
-f_{2 i} & 0 & 0 & 0
\end{array}\right) ;
$$


where $f_{1 i}=\left(\frac{N-k_{20}(x)}{D}-2\left(\frac{k \pi}{b}\right)^{2}\right) h-\frac{k_{21}}{D}$;

$$
f_{2 i}=\left(\left(\frac{k \pi}{b}\right)^{4}+\frac{k_{20}(x)}{D}\left(\frac{k \pi}{b}\right)^{2}+\frac{k_{10}(x)}{D}\right) h+\frac{1}{D}\left(k_{11}+k_{21}\left(\frac{k \pi}{b}\right)^{2}\right) \text {. }
$$

The fundamental matrix $B\left(x_{k+1}, x_{k}\right)$ QDE $\left(a_{0} y^{\prime \prime}\right)^{\prime \prime}=0$ appears [8]:

$$
B\left(x_{k+1}, x_{k}\right)=\left(\begin{array}{cccc}
1 & h & \frac{h^{2}}{2} & \frac{h^{3}}{3 !} \\
0 & 1 & h & \frac{h^{2}}{2} \\
0 & 0 & 1 & h \\
0 & 0 & 0 & 1
\end{array}\right) .
$$

The differential system fundamental matrix (28) can be found using the formula (19), getting therefore the characteristic equation.

Considering the conditions for positioning at $x=0$ point, the initial matrix $\mathbf{Y}_{0}$, appears as

Assigning

$$
\mathbf{Y}_{0}=\left(\begin{array}{ll}
0 & 0 \\
1 & 0 \\
0 & 0 \\
0 & 1
\end{array}\right)
$$

$$
B_{n}\left(x_{n}, x_{0}\right) \mathbf{Y}_{0}=\left(\begin{array}{ll}
a_{12} & a_{14} \\
a_{22} & a_{24} \\
a_{32} & a_{34} \\
a_{42} & a_{44}
\end{array}\right) .
$$

When an articulated linkage at the ending point $(x=1)$ the characteristic equation gets a form of

$$
|A(N)|=\operatorname{det}\left(\begin{array}{ll}
a_{12}(N) & a_{14}(N) \\
a_{32}(N) & a_{34}(N)
\end{array}\right)=0 .
$$

Setting the $N$ values at the predefined step, we use a PC to obtain from the (28) equation the critical forces $N_{i}$.

The comparison chart at Table 1 represents values of the three first critical forces for the compressed plate with elastic foundation and elastic supports $N_{i}$ when $k=1 ; 2 ; 3$, and for various values of $\alpha, \beta$ parameters. We proceed to solve the problem of stability for rectangular plate with articulated edges fixation when $\alpha=0, \beta=0$ and compare the result to these obtained analytically using the formula [10]:

$$
N=D \pi^{2} \frac{\left(\frac{m^{2}}{L^{2}}+\frac{n^{2}}{b^{2}}\right)}{\frac{m^{2}}{L^{2}}},
$$

where $m, n$ - number of half-waves in longitudinal and transversal directions

At calculations adopting the dividing step as $10^{-3}$ and $10^{-4}$ the frequencies' values remains unchanged in the $4^{\text {th }}$ decimal place, so, the dividing step minimizing makes no sense. 
Comparison of critical forces when the plate edges are hinged-pivot attached to the elastic foundation and elastic supports

\begin{tabular}{c|c|c|c|c|c|c|c|c}
\hline \multirow{2}{*}{$N_{i}$ Method } & \multicolumn{9}{|c|}{} & \multicolumn{3}{|c|}{ Analytical method [11 ] } & \multicolumn{3}{c}{ Proposed method } \\
\cline { 2 - 9 } & $\alpha$ & $\beta$ & $k=1$ & $k=2$ & $k=3$ & $k=1$ & $k=2$ & $k=3$ \\
\hline$N_{1}$ & 0 & 0 & 12,3567 & 45,6978 & 94,7590 & 12,3567 & 45,6978 & 94,7590 \\
\hline$N_{2}$ & 0 & 0 & 29,2466 & 49,4268 & 111,2103 & 29,2466 & 49,4268 & 111,2103 \\
\hline$N_{3}$ & 0 & 0 & 58,6963 & 76,4393 & 199,2309 & 58,6963 & 76,4393 & 199,2309 \\
\hline$N_{1}$ & 1 & 0 & - & - & - & 142,3257 & 146,9893 & 155,6261 \\
\hline$N_{2}$ & 1 & 0 & - & - & - & 252,6189 & 258,7716 & 269,6689 \\
\hline$N_{3}$ & 1 & 0 & - & - & - & 328,3047 & 335,1174 & 346,9789 \\
\hline$N_{1}$ & 1 & 1 & - & - & - & 1259,7989 & 1276,6399 & 1305,7493 \\
\hline$N_{2}$ & 1 & 1 & - & - & - & 1275,1866 & 1297,2387 & 1335,3994 \\
\hline$N_{3}$ & 1 & 1 & - & - & - & 1352,5147 & 1379,8323 & 1426,6423 \\
\hline
\end{tabular}

We consider also problems of a rectangular plate stability with elastic foundation and elastic springs when hinged pivot-attached by the lines $z=0$ and $z=b=30 \mathrm{~m}$, the longitudinal edges' along lines $x=0$ and $x=L=20 \mathrm{~m}$, being differently attached when $\alpha=\beta=1$.

Here we investigate the following conditions of a plate's longitudinal edges attachment:

1) hinged pivot: $y=0$ and $y^{[2]}=0$;

2) rigid attachment: $y=0, y^{\prime}=0$;

3) free edge: $y^{[2]}=0$ and $y^{[3]}=0$.

These three attachment conditions are conventionally identified with respective indexes $0,1,2$ to consider the problem of $(i j), i, j=0,1,2$ types. So, e.g., a problem of (01) type refers to the conditions: left plate edge being attached with an articulation link $(x=0)$, the right edge $(x=l)$ - has a rigid attachment.

The initial matrix $\mathbf{Y}_{0}$, taking into account the positioning at the point $x=0$, rigidly attached with a respectively free edge:

$$
\mathbf{Y}_{0}=\left(\begin{array}{ll}
0 & 0 \\
0 & 0 \\
1 & 0 \\
0 & 1
\end{array}\right) ; \mathbf{Y}_{0}=\left(\begin{array}{ll}
1 & 0 \\
0 & 1 \\
0 & 0 \\
0 & 0
\end{array}\right)
$$

We denote as

$$
B(l, 0) \mathbf{Y}_{0}=\left(\begin{array}{ll}
a_{11} & a_{12} \\
a_{21} & a_{22} \\
a_{31} & a_{32} \\
a_{41} & a_{42}
\end{array}\right) .
$$

Then, in compliance to the right edge attachment conditions $(x=L)$ we obtain a characteristic equation serving to evaluate respective free vibrations' frequencies for a hinged-pivotal, rigid attachment and the free edge.

$$
\operatorname{det}\left(\begin{array}{ll}
a_{11} & a_{12} \\
a_{31} & a_{32}
\end{array}\right)=0 ; \operatorname{det}\left(\begin{array}{ll}
a_{11} & a_{12} \\
a_{21} & a_{22}
\end{array}\right)=0 ; \operatorname{det}\left(\begin{array}{ll}
a_{31} & a_{32} \\
a_{41} & a_{42}
\end{array}\right)=0 .
$$


Table 2 below exposes the critical forces' values for various longitudinal attachment methods and different half-waves' number.

Table 2

Critical forces at various methods of attaching the longitudinal edges of a plate with elastic foundation and elastic supports

\begin{tabular}{c|c|c|c|c}
\hline Type & $k$ & $N_{1}$ & $N_{2}$ & $N_{3}$ \\
\hline 01 & 1 & 1238,7701 & 1259,7973 & 1263,1443 \\
\hline 11 & 1 & 1272,9984 & 1309,6605 & 1394,1699 \\
\hline 12 & 1 & 985,7169 & 1259,7272 & 1260,5716 \\
\hline 01 & 2 & 1258,5827 & 1276,4804 & 1281,8164 \\
\hline 11 & 2 & 1292,0247 & 1331,3481 & 1419,9577 \\
\hline 12 & 2 & 1006,2631 & 1298,7006 & 1355,9793 \\
\hline 01 & 3 & 1291,4108 & 1304,6889 & 1313,9039 \\
\hline 11 & 3 & 1324,5285 & 1368,3749 & 1464,0774 \\
\hline 12 & 3 & 1040,7805 & 1332,6799 & 1395,7249 \\
\hline
\end{tabular}

Conclusions. A new approximate method to calculate the critical forces for the singular type elastic foundation plates is suggested; this method departing from the approximation of corresponding differential equations' coefficients using generalized functions. The elaborated method can serve is basis for researching the loss of stability of real engineering structures having elastic foundation and elastic supports. The obtained results are principally new. This method is characterized by both the algorithm's simplicity and versatility at the same time that fast convergence achieved. Thus obtained numerical results are consistent with the known ones with appropriate parameter values.

\section{Література}

1. Власов, В.3. Балки, плиты и оболочки на упругом основании / В.3. Власов, Н.Н. Леонтьев. - М.: Физматгиз, 1960. - 492 с.

2. Alfutov, N.A. Stability of elastic structures / N.A. Alfutov. — Berlin; New York: Springer, 2000. - 337 p.

3. Численные методы в механике / В.А. Баженов [и др.]. — Одесса: СТАНДАРТЬ, 2005. - 564 с.

4. Тацій, Р. Розв'язання задач про втрату стійкості стрижнів 3 дискретно-неперервним розподілом параметрів методом дискретизації / Р. Тацій, Т. Ушак // Машинознавство. — 2009. — № 5 . — C. $41-47$.

5. Ушак, Т. Метод дискретизації в задачі про вільні коливання підкріпленої пластини / Т. Ушак // Машинознавство. — 2011. — № 1-2. - С. $10-15$.

6. Тацій, Р.М. Про апроксимацію розв’язків диференціальних рівнянь $з$ мірами / Р.М. Тацій, В.В. Іщук, В.В. Кісілевич // Вісн. Київ. ун-ту. Математика і механіка. - 1990. — № 32. - С. 128 - 131.

7. Образцов, И.Ф. Строительная механика скошенных тонкостенных систем / И.Ф. Образцов, Г.Г. Онанов. - М.: Машиностроение, 1973. - 659 с.

8. Узагальнені квазідиференціальні рівняння: монографія / Р.М. Тацій [та ін.]; Львів. держ. ун-т безпеки життєдіяльності. - Дрогобич: Коло, 2011. - 300 с.

9. Тацій, Р.М. Про структуру фундаментальної матриці квазідиференціального рівняння / Р.М. Тацій, Б.Б. Пахолок // Доп. АН УРСР. Сер. А. - 1989. — № 4. - С. $25-28$.

10. Аткинсон, Ф. Дискретные и непрерывные граничные задачи: монография / Ф. Аткинсон; пер. И.С. Иохвидов, Г.А. Каральник; ред. и авт. доп. И.С. Кац, М.Г. Крейн. - М.: Мир, 1968. — 749 с.

11. Тимошенко, С.П. Устойчивость стержней, пластин и оболочек / С.П. Тимошенко; ред. Э.И. Григолюк. - М.: Наука, 1971. — 808 с.

\section{References}

1. Vlasov, V.Z. and Leont'ev, N.N. (1966). Beams, Plates and Shells on Elastic Foundations. Jerusalem: Israel Program for Scientific Translations.

2. Alfutov, N.A. (2000). Stability of Elastic Structures. Berlin; New York: Springer. 
3. Bazhenov, V.A., Dashchenko, A.F., Kolomiets, L.V., Orobey, V.F. and Suryaninov, N.G. (2005). The Numerical Methods in Mechanics. Odessa: STANDART.

4. Tatsiy, R. and Ushak, T. (2009). Solving problems of resistance loss of rods with discretely-continuous parameters distribution by the method of digitization. Mechanical Engineering, 5, 41-47.

5. Ushak, T. (2011). Discritization method for free vibrations of supported plates. Mechanical Engineering, 1-2, 10-15.

6. Tatsiy, R.M., Ishchuk, V.V. and Kisilevych, V.V. (1990). On approximate solutions of the differential equations with measures. Visnyk Kyivskogo Universytetu: Matematyka i mekhanika, 32, 128-131.

7. Obraztsov, I.P. and Onanov, G.G. (1974). Structural Mechanics of Skewed Thin Wall Systems. WrightPatterson Air Force Base, Ohio: Foreign Technology Division.

8. Tatsiy, R.M., Stasyuk, M.F., Mazurenko, V.V. and Vlasiy, O.O. (2011). Generalized Quasi-Differential Equations. Drohobych: Kolo.

9. Tatsiy, R.M. and Pakholok, B.B. (1989). On the structure of fundamental matrix of quasi-differential equation. Dopovidi Akademii Nauk Ukrainskoi RSR: Seriya A - Fiziko-Matematichni ta Technichni Nauki, 4, 25-28.

10. Atkinson, F.V. (1964). Discrete and Continuous Boundary Problems. New York: Academic Press.

11. Tymoshenko, S.P. (1971). Stability of Rods, Plates and Shells. Moscow: Nauka.

Received March 28, 2015 